\title{
LETTER TO THE EDITOR
}

IN HER INTERESTING article on the relation between Barrett Browning's Sonnets from the Portuguese and Browning's Men and Women in Volume I4, Laura E. Haigwood follows Pettigrew in suggesting that Browning drew the title of his volume from his wife's Sonnet 26 with the intention of emphasizing the realism of his poetry in contrast to the romantic quality of hers. But it seems at least equally likely that the derivation went in the other direction.

As I observe in my Browning and Italy, Browning used the phrase as an indication of the theme of his work in at least two other contexts antedating his knowledge of Sonnets from the Portuguese besides the letter to Barrett Browning cited by Haigwood. It occurs in a letter of November 1843 to Alfred Domett, where Browning says that he is writing in a more economical style, "grudging my men and women their half-lines," and in a passage added in the 1847 revision of Pippa Passes, where his heroine speaks of "All other men and women that this earth / Belongs to ...". In a letter to Milsand of 1855 Browning explained that he employed the title because his poems were "really dramatic attempts and not a collection of miscellanies," making no reference to the sort of distinction Haigwood is concerned with. When Barrett Browning used the phrase after Browning's book had been published, she of course adopted his sense of it. Describing Browning's social activities in Rome, she said that he had "plenty of distractions, and no Men and Women. Men and women from without instead!"

It seems, therefore, that Browning privately associated the inconspicuous phrase with the nature of his poetry at an early date, and that Barrett Browning's use of it in a sonnet addressed to him may well be an assertion of her independence from him, a reversal of the situation suggested by Haigwood. 